\title{
PENGARUH PEMBERIAN BORON TERHADAP PERTUMBUHAN DAN PRODUKSI DUA VARIETAS MELON (Cucumis melo L.) PADA SISTEM HIDROPONIK MEDIA PADAT
}

\author{
Eva Dwi Rahma, Yohannes Cahya Ginting \& Azlina Heryati Bakrie \\ Jurusan Agroteknologi, Fakultas Pertanian Universitas Lampung \\ Jl. Soemantri Brodjonegoro No. 1 Bandar Lampung 35145 \\ Email: eva_dwirahma@yahoo.co.id
}

\begin{abstract}
ABSTRAK
Melon (Cucumis melo L.) merupakan tanaman hortikultura dari famili Cucurbitaceae. Pemberian unsur hara boron yang tepat dan sesuai, Serta budidaya melalui metode hidroponik di dalam rumah kaca diharapkan mampu menunjang pertumbuhan dan meningkatkan produksi buah. Penelitian bertujuan mengetahui perbedaan respons pertumbuhan dan produksi melon, konsentrasi boron terbaik dan pengaruh interaksi antara konsentrasi boron dengan varietas terhadap pertumbuhan dan produksi pada sistem hidroponik. Penelitian dilaksanakan di rumah kaca Laboratorium Lapang Terpadu Universitas Lampung. Penelitian dilakukan dengan Rancangan Acak Kelompok Lengkap (RAKL) yang disusun secara faktorial $2 \times 5$ dengan 10 perlakuan dan 3 ulangan yang disusun secara duplo. Hasil penelitian menunjukkan bahwa; terdapat perbedaan respons pertumbuhan dan produksi pada tanaman melon Varietas Action dan Varietas Aramis. Peubah panjang tanaman, bobot buah, volume dan ketebalan daging buah melon varietas Action lebih tinggi daripada varietas Aramis; pengaruh pemberian boron pada konsentrasi $0,1-1,3 \mathrm{ppm}$ terhadap diameter buah sudah mencapai titik maksimum. Diameter buah tertinggi diperoleh dari pemberian konsentrasi boron $0,6 \mathrm{ppm}$ yaitu sebesar $14,10 \mathrm{~cm}$; pengaruh pemberian boron pada konsentrasi $0,1-1,3 \mathrm{ppm}$ menghasilkan respons yang berbeda terhadap varietas. Pada varietas Action, Panjang tanaman tertinggi diperoleh dari pemberian boron $0,7 \mathrm{ppm}$ sebesar $231,73 \mathrm{~cm}$. Sedangkan varietas Aramis, setiap peningkatan boron $0,3 \mathrm{ppm}$ panjang tanaman mengalami penurunan sebesar 2,01 cm. Pada varietas Aramis, Bobot buah terbesar diperoleh dari pemberian konsentrasi boron $0,8 \mathrm{ppm}$ yaitu sebesar 1.685 gram. Setiap peningkatan $0,3 \mathrm{ppm}$, bobot buah mengalami penurunan sebesar 72,95 gram.
\end{abstract}

Kata kunci : varietas, boron, pertumbuhan, produksi.

\section{PENDAHULUAN}

Melon merupakan tanaman semusim dan bersifat herbacious (Ashari, 1995). Menurut data Badan Pusat Statistik (BPS ${ }^{\mathrm{b}}$ ) jumlah penduduk Indonesia pada tahun 2010 mencapai 237.556.363 jiwa, sedangkan konsumsi buah melon Indonesia mencapai \pm 332.698 ton per tahun Pada tahun 2010, produksi melon di Indonesia hanya sebesar 85.161 ton sehingga tidak dapat memenuhi kebutuhan melon di dalam negeri. Akibatnya 247.537 ton buah melon harus diimpor dari luar negeri. Konsumsi buah melon yang terus bertambah dari tahun ke tahun sangat mendukung perkembangan melon di Indonesia ( BPS, 2012a).

Varietas melon yang digunakan adalah Varietas Action dan Aramis. Varietas Action memiliki bentuk buah bulat oval dengan bobot $2,1-4,0 \mathrm{~kg}$. Daging buahnya tebal berwarna hijau kekuningan, memiliki aroma tidak begitu tajam dan buah tahan disimpan lama, sehingga cocok untuk pengiriman jarak jauh. Potensi produksi 30-40 ton (PT Bisi, 2008). Sedangkan untuk varietas Aramis, yang diterangkan dalam Berita Resmi PVT No. 04/BR/PVHP/04/2012 tentang Pendaftaran Varietas
Hasil Pemuliaan sebagai varietas unggul, memiliki bentuk buah bulat dengan bobot 2,2-2,8 kg. Daging buah tebal berwarna putih kehijauan, aromanya harum, dan potensi produksi mencapai $49-58$ ton.

Bertanam melon dengan metode hidroponik di dalam rumah kaca memiliki kualitas buah yang lebih tinggi, buah yang dihasilkan tanaman meningkat dan memungkinkan bagi petani untuk melakukan pembibitan diluar musim. Studi percobaan CSIRO (Organisasi/ lembaga penelitian ilmu pengetahuan negara-negara persemakmuran) di Griffith, New South Wales Australia, selama periode tahun 1960-1970 menunjukkan bahwa produktivitas dari sebuah rumah kaca meningkat delapan kali lipat dibandingkan dengan pengolahan di lahan terbuka (Elviza et al., 1999).

Pada budidaya tanaman melon, unsur hara boron dibutuhkan dalam jumlah yang relatif kecil. Pemberian boron diharapkan dapat memperkuat dinding sel dan meningkatkan pertumbuhan secara optimal. Boron berperan penting dalam sintesis salah satu dasar pembentukan RNA pada pembentukan sel misalnya pembelahan sel, pendewasaan sel, respirasi atau pernapasan dan pertumbuhan (Sutiyoso, 2003). Boron 
tidak dapat dipindahkan dari satu jaringan ke jaringan yang lain, sehingga gejala awal terlihat pada jaringan muda misalnya kematian pucuk. Jika terjadi kekurangan boron, sel-sel tanaman tetap membelah, tetapi organorgan struktural, seperti daun, cabang, atau bunga gagal terbentuk (Novizan, 2005).

Menurut Yuste dan Gostincar, 1999; dalam Jones, 2005 bahwa konsentrasi nutrisi boron yang digunakan dalam hidroponik berkisar antara $0,1-1,0 \mathrm{ppm}$. Pada dataran rendah seperti di Lampung, belum ada data mengenai konsentrasi boron terbaik untuk melon. Sehingga pada penelitian ini, konsentrasi boron yang digunakan yaitu $0,1 \mathrm{ppm} ; 0,4 \mathrm{ppm} ; 0,7 \mathrm{ppm} ; 1,0 \mathrm{ppm}$ dan 1,3 ppm. Konsentrasi dipakai untuk mengetahui kebutuhan boron tanaman pada konsentrasi rendah dan tinggi. Penelitian bertujuan mengetahui perbedaan respons pada pertumbuhan dan produksi dua varietas tanaman melon melalui metode hidroponik, mengetahui konsentrasi boron terbaik, dan mengetahui interaksi antara konsentrasi boron dengan varietas melon terhadap pertumbuhan dan produksi buah.

\section{BAHAN DAN METODE}

Tempat Penelitian. Penelitian dilaksanakan di rumah kaca Laboratorium Lapang Terpadu Universitas Lampung pada bulan Agustus 2013 sampai Oktober 2013.

Bahan. Bahan yang digunakan dalam penelitian ini adalah benih melon hibrida varietas Action dan Aramis, Pupuk NPK mutiara, Urea, kalsium klorida, magnesium sulfat, besi sulfat, mangan sulfat, asam boraks, tembaga sulfat, seng sulfat, natrium sulfat, natrium molibdat, polibag, benang kasur, tali rafia, aquades dan arang sekam.

Metode. Rancangan yang digunakan Rancangan Acak Kelompok Lengkap (RAKL). Perlakuan disusun secara faktorial 2x5 dengan 10 perlakuan dan 3 ulangan yang disusun secara duplo. Faktor pertama adalah varietas melon yaitu Varietas Action $\left(\mathrm{V}_{1}\right)$ dan Aramis $\left(\mathrm{V}_{2}\right)$. Faktor kedua adalah perlakuan Boron yaitu $b_{1}=0,1 \mathrm{ppm}$; $\mathrm{b}_{2}=0,4 \mathrm{ppm} ; \mathrm{b}_{3}=0,7 \mathrm{ppm} ; \mathrm{b}_{4}=1,0$ ppm dan $\mathrm{b}_{5}=1,3 \mathrm{ppm}$.

Pelaksanaan. Benih melon yang telah disemai berumur tujuh hari dipindahkan ke dalam polybag yang berisi media arang sekam. Penyiraman dilakukan 3\%4 kali sehari dengan larutan hara yang telah terdapat unsur boron, dengan konsentrasi boron (B) sesuai perlakuan (0,1 ppm; 0,4 ppm; 0,7 ppm; 1,0 ppm; dan 1,3 ppm), tiap penyiraman $250 \% 500 \mathrm{ml}$ per tanaman. Penyiraman dilakukan selama 65 hari setelah pindah tanam. Dosis atau kebutuhan boron selama penelitian adalah pada konsentrasi 0,1 ppm sebanyak 11,55 g/tan; 0,4 ppm sebanyak 46,20 g per tanaman; 0,7 ppm sebanyak 80,85 g per tanaman; 1,0 ppm sebanyak 115,5 g per tanaman; dan pada 1,3 ppm sebanyak $150,15 \mathrm{~g}$ per tanaman. Variabel yang diamati yaitu panjang tanaman $(\mathrm{cm})$, jumlah daun (helai), bobot kering tanaman (g), jumlah bunga (kuntum), bobot buah $(\mathrm{kg})$, diameter buah $(\mathrm{cm})$, volume buah $(\mathrm{ml})$, ketebalan daging $(\mathrm{cm})$ dan kadar brix $(\%)$.

\section{HASIL DAN PEMBAHASAN}

Pertumbuhan melon varietas Action lebih baik dibandingkan dengan Varietas Aramis. Perlakuan boron memberikan pengaruh terhadap pertumbuhan dan produksi melon. Melon varietas Action sesuai untuk dikembangkan terutama di wilayah lampung. Melon varietas Action bisa beradaptasi pada daerah 0-600 m dpl (PT Bisi, 2008). Sedangkan ketinggian tempat di Laboratorium lapang terpadu Universitas Lampung yaitu 146 m dpl (Deviana, 2013). Ketinggian tempat yang optimal untuk budidaya tanaman melon adalah 200$900 \mathrm{~m}$ dpl. Namun tanaman melon masih dapat berproduksi dengan baik pada ketinggian $0-100 \mathrm{~m} \mathrm{dpl,}$ sedangkan pada ketinggian lebih dari $900 \mathrm{~m}$ dpl tanaman melon tidak dapat berproduksi optimal (Siswanto, 2010). Sehingga untuk wilayah lampung sudah sesuai untuk dikembangkan budidaya melon secara luas.

Pada penelitian ini terlihat perlakuan boron memberikan pengaruh yang nyata pada pertumbuhan dan produksi melon (Tabel 1). Hal ini terlihat pada saat fase vegetatif dan generatif tanaman melon. Boron berpengaruh nyata terhadap panjang tanaman, bobot kering tanaman, bobot buah, volume buah, diameter buah dan tebal daging buah (Gambar 1-6). Namun pengaruh terhadap variabel pengamatan bersifat nyata pada konsentrasi $0,1-0,7 \mathrm{ppm}$. Pada variabel panjang tanaman berpengaruh nyata pada semua konsentrasi boron. Setiap peningkatan konsentrasi boron sebesar $0,3 \mathrm{ppm}$, panjang tanaman meningkat $4,44 \mathrm{~cm}$. Panjang tanaman tertinggi diperoleh dari pemberian boron pada konsentrasi 0,7 ppm yaitu sebesar 231,73 cm. Menurut Mengel dan Kirby (1982) kelebihan boron yang dapat menimbulkan keracunan bagi tanaman jumlahnya belum diketahui secara pasti tergantung varietas tanaman.

Rendahnya produksi tanaman melon kemungkinan disebabkan karena proses respirasi yang terjadi pada tanaman. Tingginya respirasi yang terjadi pada tanaman menyebabkan tingginya penggunaan fotosintat, hal ini menyebabkan tanaman memerlukan suplai nutrisi 
Tabel 1. Pengaruh varietas dan pemberian boron terhadap pertumbuhan tanaman melon pada fase vegetatif

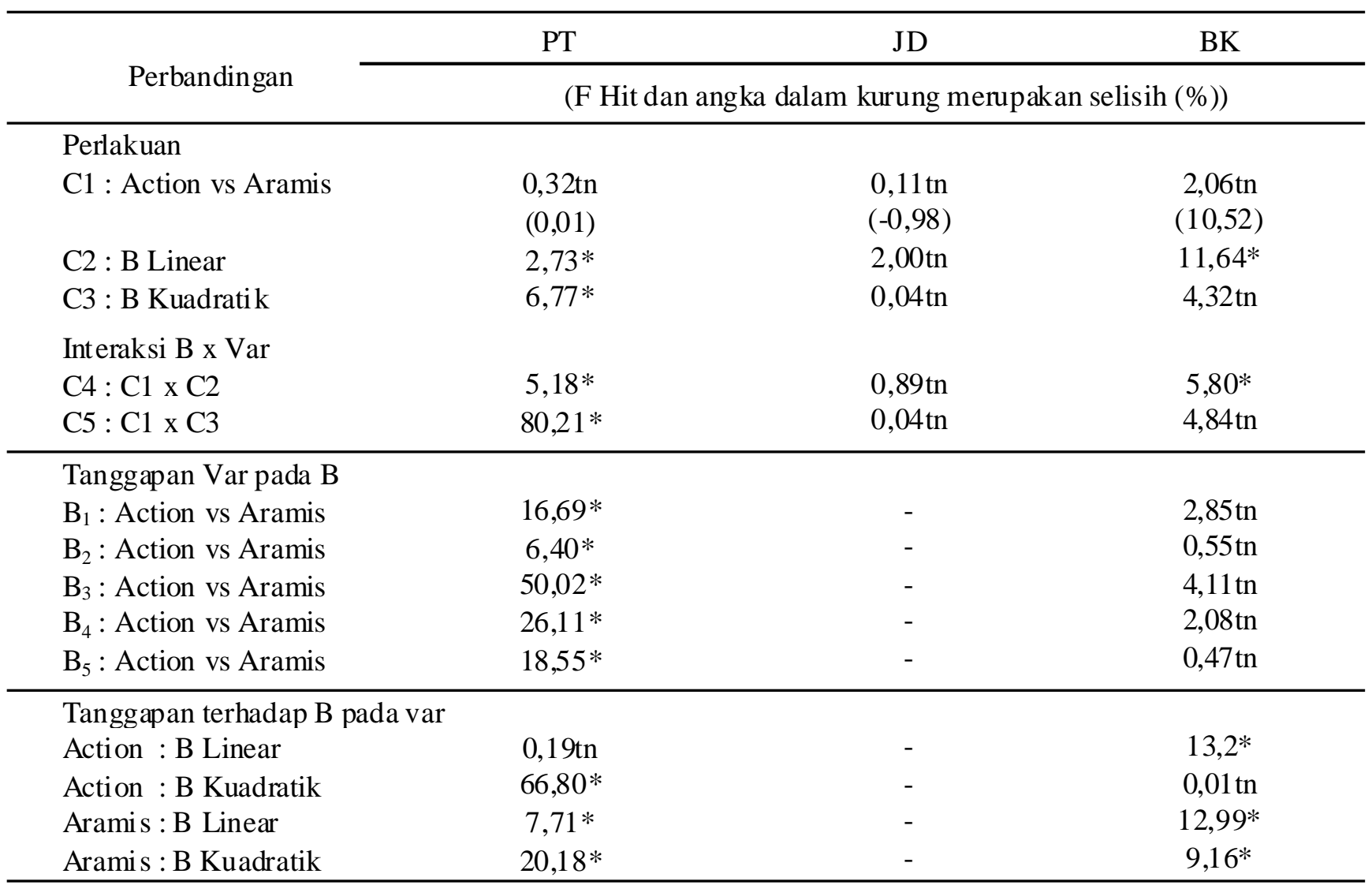

Keterangan: F Tabel $0,05=4,41, *$ = berpengaruh nyata pada taraf á $0,05, \mathrm{tn}=$ tidak berpengaruh nyata pada taraf $\alpha$ 0,05, Variabel pengamatan: $\mathrm{PT}=$ Panjang Tanaman, $\mathrm{JD}=\mathrm{Jumlah}$ Daun, $\mathrm{BKB}=$ Bobot Kering Brangkasan.

semakin tinggi. Pada saat kekurangan nutrisi, sebagian stomata daun menutup sehingga terjadi hambatan keluarnya $\mathrm{CO}_{2}$ dan menurunkan aktivitas respirasi (Ai dan Banyo, 2011). Menurut Ai (2012), boron mempunyai peran dalam transportasi karbohidrat hasil dari fotosintesis. Karbohidrat terlibat pada penyimpanan dan pemakaian energi yang digunakan untuk pertumbuhan tanaman, sehingga dengan pemberian unsur boron dapat mengoptimalkan pertumbuhan tanaman. Respons tanaman sebagai akibat faktor lingkungan terlihat pada penampilan tanaman (Gardner et al., 1991). Boron yang tidak dapat diserap tanaman secara optimal, menyebabkan pertumbuhan vegetatif tanaman pada masing-masing varietas melon menjadi terhambat (Wijayani dan Widodo, 2005).

Pada pengamatan pascapanen terlihat bahwa varietas Action menghasilkan bobot buah yang lebih besar dibandingkan varietas Aramis (Tabel 2). Produksi buah melon ditentukan oleh bobot buah, sedangkan bobot buah ditentukan oleh diameter dan ketebalan daging buah. Pemberian boron pada tanaman berpengaruh terhadap meningkatnya diameter buah dan cenderung meningkatkan panjang buah (Kurniasari, 1994). Setiap peningkatan konsentrasi boron sebesar 0,3 ppm, bobot buah melon varietas Action mengalami peningkatan sebesar 58,5 gram. Bobot buah terbesar diperoleh dari pemberian boron pada konsentrasi 0,8 ppm yaitu sebesar 1.685 gram. Pada varietas Aramis, setiap peningkatan pemberian boron $0,3 \mathrm{ppm}$, bobot buah mengalami penurunan sebesar 72,95 gram (Gambar 3). Hal ini sesuai dengan pendapat Lorenz dan Maynard (1980) bahwa kandungan boron yang kritikal berada pada kisaran 0,1-0,8 ppm. Menurut Untung (2001), defisiensi B mungkin terjadi jika kandungannya kurang dari kisaran tersebut. Dan kelebihan boron pada tanaman dapat menyebabkan ujung daun kuning, diikuti nekrosis di tempat tersebut.

Kadar brix buah melon varietas Action mencapai 7,2-13,4 \% (Siswanto, 2010). Sedangkan varietas Aramis memiliki kadar brix sebesar $11-13 \%$ (Rokhman, 2013). Pada penelitian yang dilakukan, kadar brix yang didapat pada varietas Action sebesar 5,3$10,2 \%$. Sedangkan varietas Aramis memiliki kandungan brix sebesar 6,8-11,2\%. Rendahnya kadar brix pada 


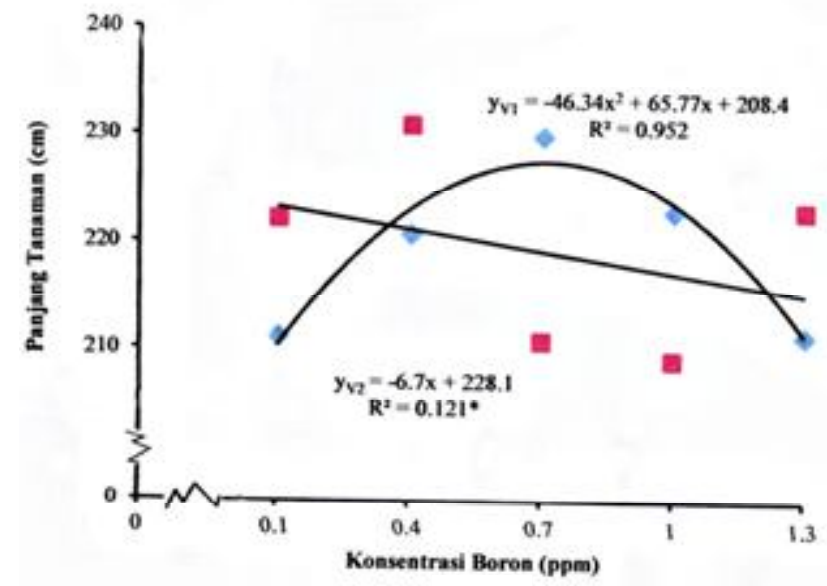

A

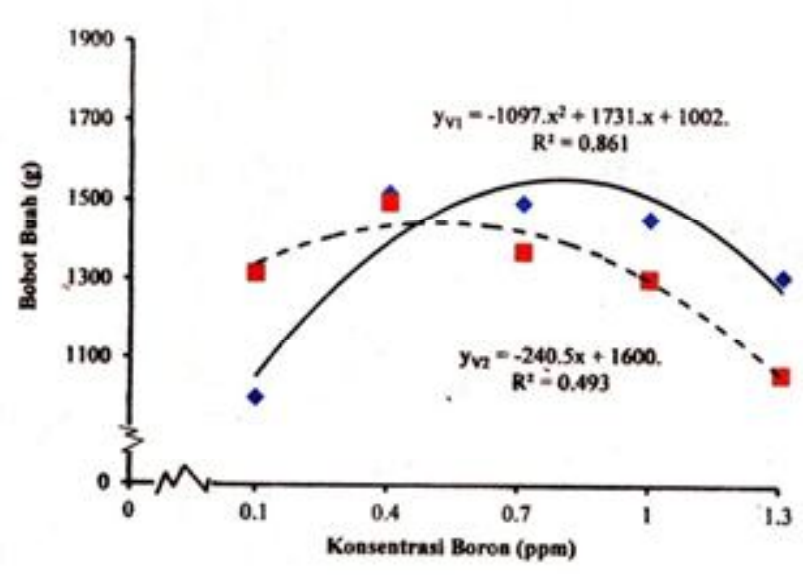

C

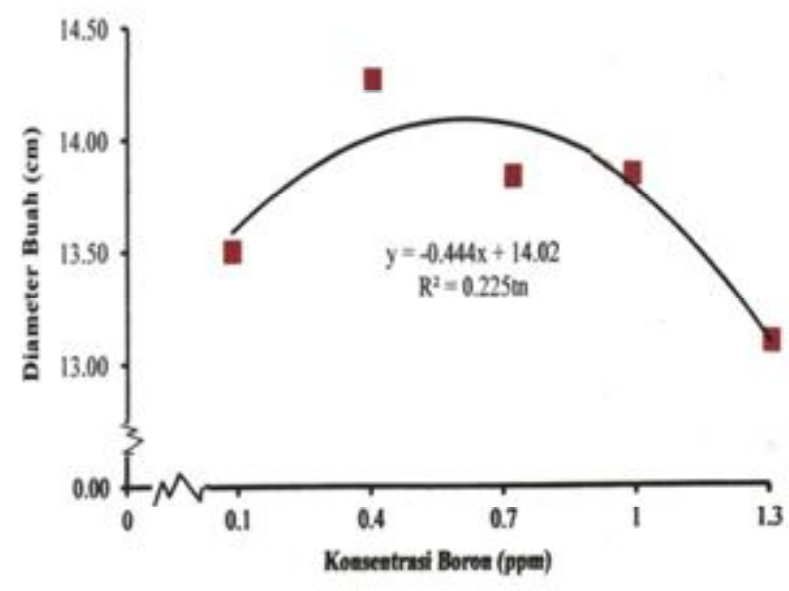

$\mathbf{E}$

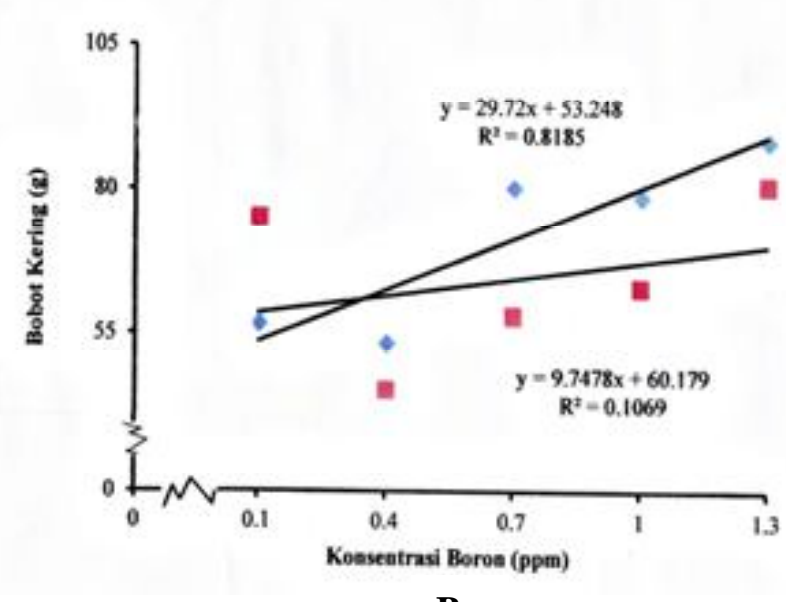

B

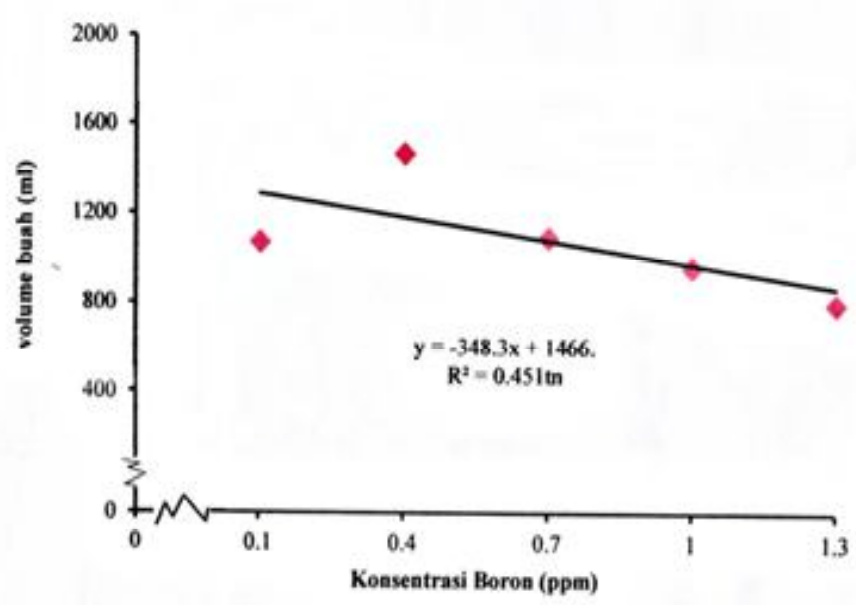

D

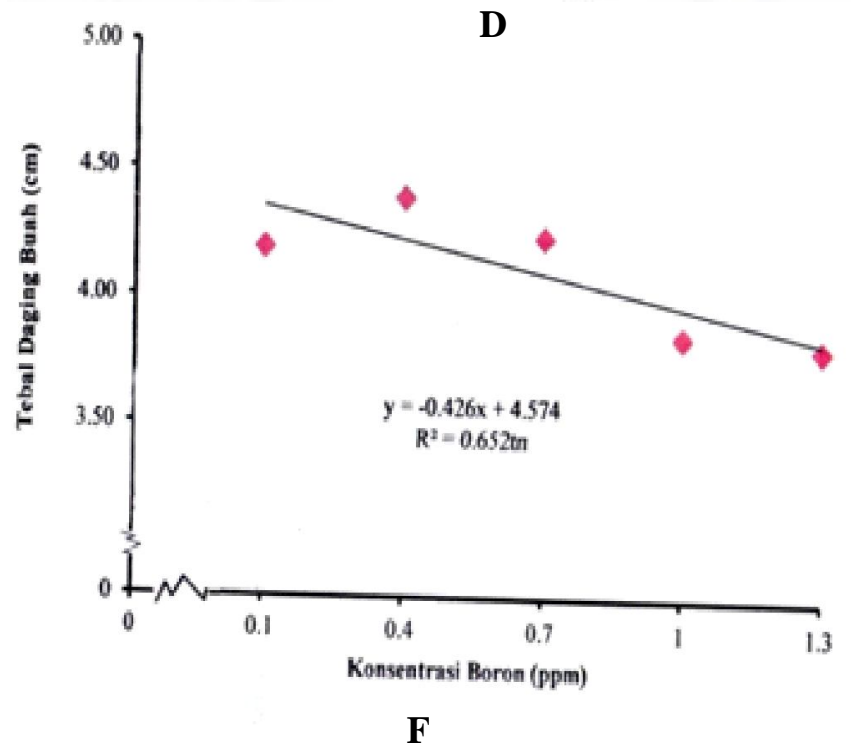

Gambar 1. Hubungan antara konsentrasi boron dan panjang tanaman (A), bobot kering brangkasan (B), bobot buah (C), volume buah (D), diameter buah (E), ketebalan daging buah melon (F). = Aramis, * Actions.

buah dipengaruhi rendahnya kandungan unsur hara di dalam media tanam. Kadar gula pada buah selalu meningkat karena terjadinya degradasi karbohidrat dan menurun pada hari tertentu karena gula yang digunakan untuk proses respirasi akan diubah menjadi senyawa lainnya. Total gula selanjutnya digunakan untuk melakukan aktivitas seluruh sisa hidup dari buah tersebut (Siswanto, 2010). 
Tabel 2. Pengaruh varietas dan pemberian boron terhadap fase generatif dan produksi tanaman melon

\begin{tabular}{|c|c|c|c|c|c|c|}
\hline \multirow{2}{*}{ Perbandingan } & $\mathrm{JB}$ & $\mathrm{BB}$ & VB & DB & $\mathrm{TD}$ & $\mathrm{KB}$ \\
\hline & \multicolumn{6}{|c|}{ (F Hit dan angka dalam kurung merupakan selisih (\%)) } \\
\hline \multicolumn{7}{|l|}{ Perlakuan } \\
\hline C1 : Action vs Aramis & $\begin{array}{l}0,14 \text { tn } \\
(-1,32)\end{array}$ & $\begin{array}{l}0,66 \text { tn } \\
(3,30)\end{array}$ & $\begin{array}{l}0,54 \mathrm{tn} \\
(4,81)\end{array}$ & $\begin{array}{c}0,01 \text { tn } \\
(0,34)\end{array}$ & $\begin{array}{l}0,09 \mathrm{tn} \\
(0,53)\end{array}$ & $\begin{array}{c}4,43^{*} \\
(11,74)\end{array}$ \\
\hline C2 : B Linear & $0,16 \mathrm{tn}$ & $0,11 \mathrm{tn}$ & $11,04 *$ & $2,90 \mathrm{tn}$ & $8,36^{*}$ & $0,05 \mathrm{tn}$ \\
\hline C3 : B Kuadratik & 0,20 tn & $20,08^{*}$ & $6,24^{*}$ & $8,74 *$ & $2,31 \mathrm{tn}$ & $0,58 \mathrm{tn}$ \\
\hline \multicolumn{7}{|l|}{ Interaksi B x Var } \\
\hline $\mathrm{C} 4: \mathrm{C} 1 \times \mathrm{C} 2$ & 0,02 tn & 2,98 th & $2,28 \mathrm{tn}$ & $1,51 \mathrm{tn}$ & $0,002 \mathrm{tn}$ & $4,40 \mathrm{tn}$ \\
\hline $\mathrm{C} 5: \mathrm{C} 1 \times \mathrm{C} 3$ & $1,05 \mathrm{tn}$ & $4,84^{*}$ & $0,35 \mathrm{tn}$ & $2,07 \mathrm{tn}$ & $0,50 \mathrm{tn}$ & $2,95 \mathrm{tn}$ \\
\hline \multicolumn{7}{|l|}{ Tanggapan Var pada B } \\
\hline B1 : Action vs Aramis & - & $6,39 *$ & - & - & - & - \\
\hline B2 : Action vs Aramis & - & 0,03 tn & - & - & - & - \\
\hline B3 : Action vs Aramis & - & $0,96 \mathrm{tn}$ & - & - & - & - \\
\hline B4 : Action vs Aramis & - & 1,44 tn & - & - & - & - \\
\hline B5 : Action vs Aramis & - & 3,90 tn & - & - & - & - \\
\hline \multicolumn{7}{|c|}{ Tanggapan terhadap B pada var } \\
\hline Action : B Linear & - & $4,03 \mathrm{tn}$ & - & - & - & - \\
\hline Action : B Kuadratik & - & $16,08^{*}$ & - & - & - & - \\
\hline Arami s : B Linear & - & $6,13^{*}$ & - & - & - & - \\
\hline Arami s : B Kuadratik & - & $5,42^{*}$ & - & - & - & - \\
\hline
\end{tabular}

Keterangan: F Tabel $0,05=4,41,{ }^{*}=$ berpengaruh nyata pada taraf $\alpha 0,05, \mathrm{tn}=$ tidak berpengaruh nyata pada taraf $\alpha$ 0,05, Variabel pengamatan: $\mathrm{JB}=$ Jumlah Bunga, $\mathrm{BB}=$ Bobot Buah, $\mathrm{VB}=$ Volume Buah, $\mathrm{DB}=$ Diameter Buah, $\mathrm{TD}=$ Ketebalan Daging Buah, $\mathrm{KB}=$ Kadar Brix.

Pertumbuhan melon varietas Action lebih baik dibandingkan dengan Varietas Aramis. Perlakuan boron memberikan pengaruh terhadap pertumbuhan dan produksi melon. Hal ini terlihat pada saat fase vegetatif dan generatif tanaman melon. Boron berpengaruh nyata terhadap panjang tanaman, bobot kering tanaman, bobot buah, volume buah, diameter buah dan tebal daging buah. Panjang tanaman tertinggi diperoleh dari pemberian boron pada konsentrasi 0,7 ppm yaitu sebesar $231,73 \mathrm{~cm}$. Boron mempunyai peran dalam transportasi karbohidrat hasil dari fotosintesis. Karbohidrat terlibat pada penyimpanan dan pemakaian energi yang digunakan untuk pertumbuhan tanaman, sehingga dengan pemberian unsur boron dapat mengoptimalkan pertumbuhan tanaman. Respons tanaman sebagai akibat faktor lingkungan terlihat pada penampilan tanaman. Boron yang tidak dapat diserap tanaman secara optimal, menyebabkan pertumbuhan vegetatif tanaman pada masing-masing varietas melon menjadi terhambat. Pada pengamatan pascapanen terlihat bahwa varietas Action menghasilkan bobot buah yang lebih besar dibandingkan varietas Aramis. Pemberian boron pada tanaman berpengaruh terhadap meningkatnya diameter buah dan cenderung meningkatkan panjang buah. Pada varietas Action, bobot buah terbesar diperoleh dari pemberian boron pada konsentrasi 0,8 ppm yaitu sebesar 1.685 gram. Defisiensi B mungkin terjadi jika kandungannya kurang dari kisaran tersebut. Dan kelebihan boron pada tanaman dapat menyebabkan ujung daun kuning, diikuti nekrosis di tempat tersebut. Rendahnya kadar brix pada buah dipengaruhi rendahnya kandungan unsur hara di dalam media tanam. Kadar gula pada buah selalu meningkat karena terjadinya degradasi karbohidrat dan menurun pada hari tertentu karena gula yang digunakan untuk proses respirasi akan diubah menjadi senyawa lainnya. Total gula selanjutnya digunakan untuk melakukan aktivitas seluruh sisa hidup dari buah tersebut. 


\section{KESIMPULAN}

Terdapat perbedaan respons pertumbuhan dan produksi pada tanaman melon Varietas Action dan Varietas Aramis. Perkembangan panjang tanaman, bobot buah, volume dan ketebalan daging buah melon varietas Action lebih tinggi daripada varietas Aramis. Diameter buah tertinggi diperoleh dari pemberian boron $0,6 \mathrm{ppm}$ yaitu sebesar $14,10 \mathrm{~cm}$. Pengaruh pemberian boron pada konsentrasi $0,1-1,3$ ppm menghasilkan respons yang berbeda terhadap varietas. Pada varietas Action, Panjang tanaman tertinggi diperoleh dari pemberian boron $0,7 \mathrm{ppm}$ sebesar $231,73 \mathrm{~cm}$. Sedangkan varietas Aramis, peningkatan boron 0,3 ppm panjang tanaman mengalami penurunan $2,01 \mathrm{~cm}$. Pada varietas Action, bobot buah terbesar diperoleh dari pemberian boron 0,8 ppm yaitu 1.685 gram. Pada varietas Aramis, setiap peningkatan $0,3 \mathrm{ppm}$, bobot buah mengalami penurunan sebesar 72,95 gram.

\section{DAFTAR PUSTAKA}

Ai, N. S. dan Y. Banyo. 2011. Konsentrasi Klorofil Daun Sebagai Indikator Kekurangan Air

pada Tanaman. Universitas Sam Ratulangi. Manado. J. Ilmiah Sains 11(2): 166-173.

Ai, N.S. 2012. Evolusi Fotosintesis pada Tumbuhan. Universitas Sam Ratulangi. Manado.J. Ilmiah Sains 12(1): 1-34.

Ashari, P.R. 2008. Peningkatan Kualitas Anthurium hookeri Melalui Pemberian Unsur Boron (B). Universitas Sebelas Maret. Surakarta. $45 \mathrm{Hlm}$.

Astuti, T.M., Santosa., K. Dewi. dan A.A. Prawoto. 2007. Alokasi Fotosintat pada Kakao dengan Perunut Boron. Dalam: Buletin Ilmiah Instiper. Yogyakarta. J. 14(2): 33-31.

Berita Resmi PVT. 2012. Pendaftaran Varietas Hasil Pemuliaan Melon Aramis. http://ppvt. setjen.pertanian.go.id/ppvtpp/files/ BR\%20Haspem\%204.PDF. Diakses pada tanggal 10 Desember 2013. $1 \mathrm{Hlm}$.

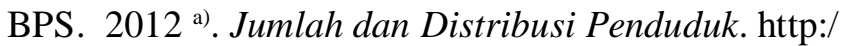
/sp2010.bps.go.id/index.php. Diakses pada tanggal 9 Mei 2012. $1 \mathrm{Hlm}$.

BPS. 2012 ${ }^{\text {b) }}$ Produksi Sayuran di Indonesia. http:/ /www.bps.go.id/tab_sub/view.php. Diakses pada tanggal 24 November 2012. $2 \mathrm{Hlm}$.
Deviana, M. 2013. Uji Efektifitas Anorganik dan Kombinasinya dengan Pupuk Organonitrofos terhadap Produksi dan Serapan Hara Tanaman Jagung (Zea mays L.) di Tanah Ultisol Gedong Meneng pada Musim Tanam ke Dua. Universitas Lampung.Bandar Lampung. $23 \mathrm{hlm}$.

Elviza, M., M. Puspita., A.M. Sadikin., N.D. Susnengtioko., Y. Ramdhan., dan R. Triani. 1999. Petunjuk Tentang Hidroponik. Universitas Padjadjaran. Bandung. $9 \mathrm{Hlm}$.

Gardner, F., R. Brent Pearce., and R.L. Mitchell. 1991. Fisiologi Tanaman Budidaya. Diterjemahkan Oleh Herawati Susilo. UI Press. Jakarta.

Jones, J.B. 2005. Hidroponics: a Practical Guide for the Soilless Grower Second Edition. CRC Press. Boca Raton, London. Pp. 94.

Kurniasari, H. 1994. Pengaruh Pemberian Pupuk Kalium dan Boron terhadap Pertumbuhan dan Produksi Semangka (Citrullus vulgaris Schard.). Institut Pertanian Bogor. $30 \mathrm{Hlm}$.

Lorenz, O. A. and D. N Maynard. 1980. Knott's Handbook for Vegetable Grower. Edition II.

John Wiley and Sons Inc. New York. Pp. 390.

Mengel, K. and Kirby. 1982. Principles of Plant Nutrition. Int. Potast Inst. Switzerland. Pp. 687.

Novizan. 2005. Petunjuk Pemupukan yang Efektif. Agro Media Pustaka. Tangerang. $75 \mathrm{Hlm}$.

PT. Bisi Internasional. 2008. Deskripsi Tanaman Melon Action. http://www.bisi.co.id/hybridseed. php?locks=product. Diakses pada tanggal 9April 2014.

Rokhman, F. 2013. Deskripsi Tanaman Melon Aramis. PT. East West Seed Indonesia. Varietas.net/dbvarietas/ variemage/melon $\% 20(\mathrm{OK})$.pdf. Diakses pada tanggal 2 Desember 2013. $1 \mathrm{Hlm}$.

Siswanto. 2010. Meningkatkan Kadar Gula Buah Melon. UPN Veteran. Jawa Timur. $82 \mathrm{Hlm}$.

Sutiyoso, Y. 2003. Meramu Pupuk Hidroponik. Penebar Swadaya. Jakarta. $121 \mathrm{Hlm}$.

Untung, O. 2001. Hidroponik Sayuran Sistem NFT. Penebar Swadaya. Jakarta. 67 Hlm. 
Wijayani dan Widodo.2009. http://agrisci.ugm.ac.id/ vol12_1/9.hidroponik_ari.pdf.Usaha Meningkatkan Kualitas Beberapa Varietas Tanaman dengan Sistem Budidaya Hidroponik. Diakses pada tanggal 5 Mei 2012.1 Hlm. 